ORIGINAL ARTICLE / ARTIGO ORIGINAL

\title{
HIV/AIDS Knowledge among MSM in Brazil: a challenge for public policies
}

\section{Conhecimento sobre HIV / aids entre HSH no Brasil: um desafio para as politicas públicas}

\author{
Mark Drew Crosland Guimarães' (1D), Laio Magno ${ }^{\prime \prime, I I I}$ (D), Maria das Graças Braga Ceccato' (D), \\ Raquel Regina de Freitas Magalhães Gomes ${ }^{\mathrm{V}}{ }^{(\mathbb{D}}$, Andrea Fachel Leal ${ }^{\mathrm{V}}$ (D), \\ Daniela Riva Knauth ${ }^{\mathrm{VI}}$ (D), Maria Amélia de Sousa Mascena Veras ${ }^{\mathrm{VII}}$ (iD), Inês Dourado ${ }^{\mathrm{III}}$ (D),

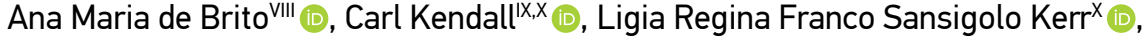 \\ The Brazilian HIV/MSM Surveillance Group*
}

\begin{abstract}
Introduction: High level of HIV/AIDS knowledge is required for an effective adoption of preventive strategies. Objective: To assess HIV/AIDS knowledge among men who have sex with men (MSM) in 12 Brazilian cities. Methods: Respondent-Driven Sampling method was used for recruitment. HIV/AIDS knowledge was assessed by Item Response Theory. Difficulty and discrimination parameters were estimated, and the knowledge score was categorized in three levels: high, medium, and low. Logistic regression was used for analysis. Results: Among 4,176 MSM, the proportion of high level of knowledge was $23.7 \%$. The following variables were positively associated with high knowledge $(p<0.05)$ : age $25+$ years old, $12+$ years of schooling, white skin color, having health insurance, having suffered discrimination due to sexual orientation, having had a syphilis test, and having received educational material in the previous 12 months. Exchanging sex for money was negatively associated. Conclusions: The proportion of only $23.7 \%$ of high HIV/AIDS knowledge was low. We should note that the only potential source of knowledge acquisition associated with high level of knowledge was receiving educational materials. Our study indicates the need for expansion of public prevention policies focused on MSM and with more effective communication strategies, including the development of knowledge that involves motivation and abilities for a safer behavior.
\end{abstract}

Keywords: HIV. Acquired Immunodeficiency Syndrome. Knowledge. Item Response Theory. RDS. MSM. Brazil.

*Alexandre Kerr Pontes, Ana Cláudia Camillo, Ana Maria de Brito, Ana Rita Coimbra Motta-Castro, Daniela Riva Knauth, Andréa Fachel Leal, Edgar Merchan-Hermann, Ximena Pamela Diaz, Luana Nepomuceno Gondim Costa Lima, Maria Amélia Veras, Inês Dourado, Lígia Regina Franco Sansigolo Kerr, Lisangela Cristina de Oliveira, Mark Drew Crosland Guimarães, Raimunda Hermelinda Maia Macena, Rosa Salani Mota, Maria do Socorro Cavalcante, Carl Kendall, Cristina Pimenta, Ana Roberta Pati Pascom.

Universidade Federal de Minas Gerais - Belo Horizonte (MG), Brazil.

"Department of Life Sciences, Universidade do Estado da Bahia - Salvador (BA), Brazil.

I"Institute of Collective Health, Universidade Federal da Bahia - Salvador (BA), Brazil.

IV Municipal Department of Health of Belo Horizonte - Belo Horizonte (MG), Brazil.

vDepartment of Sociology, Institute of Philosophy and Humanities. Universidade Federal do Rio Grande do Sul - Porto Alegre (RS), Brazil

v'Department of Social Medicine, School of Medicine, Universidade Federal do Rio Grande do Sul - Rio Grande (RS), Brazil.

VIISchool of Medical Sciences of Santa Casa de São Paulo - São Paulo (SP), Brazil

VIIIAggeu Magalhães Institute, Oswaldo Cruz Foundation - Recife (PE), Brazil.

IxTulane School of Public Health and Tropical Medicine - New Orleans (LA), United States of America.

xDepartment of Community Health, Federal University of Ceará - Fortaleza (CE), Brazil.

Corresponding author: Mark Drew Crosland Guimarães. Department of Preventive and Social Medicine. School of Medicine. Universidade Federal de Minas Gerais. Avenida Alfredo Balena, 190, Santa Efigênia, CEP: 30130-100, Belo Horizonte, MG, Brazil. E-mail: mark.guimaraes@gmail.com

Conflict of interests: nothing to declare - Financial support: Brazilian Ministry of Health, through the Department of Health Surveillance and the Department of Surveillance, Prevention and Control of STD, HIV/AIDS and Viral Hepatitis. 
RESUMO: Introdução: Alto nível de conhecimento sobre HIV/aids é necessário para uma efetiva adoção de estratégias preventivas. Objetivo: Avaliar o nível de conhecimento sobre HIV/aids entre homens que fazem sexo com homens (HSH) de 12 cidades brasileiras. Metodologia: O método Respondent-Driven Sampling foi utilizado para recrutamento. O conhecimento sobre HIV/aids foi avaliado por meio de 12 perguntas e analisados pela Teoria de Resposta ao Item. Foram estimados os parâmetros de dificuldade e discriminação e o escore de conhecimento categorizado em três níveis: alto, médio e baixo. Regressão logística foi utilizada para a análise. Resultados: Do total de $4.176 \mathrm{HSH}$, a proporção de alto nível de conhecimento foi de $23,7 \%$. Estiveram associados positivamente $(\mathrm{p}<0,05)$ com o alto conhecimento: idade $25+$ anos, escolaridade $12+$ anos, cor da pele branca, ter plano de saúde, ter sofrido discriminação devido à orientação sexual, ter realizado teste para sífilis e recebido material educativo nos últimos 12 meses. Ter recebido dinheiro por sexo esteve negativamente associado. Conclusões: A proporção de apenas $23,7 \%$ de alto nível de conhecimento sobre HIV/aids foi baixa. Destaca-se que a única potencial fonte formal de aquisição de conhecimento associada com alto nível de conhecimento foi receber material educativo. Este estudo aponta a necessidade de expandir as políticas públicas de prevenção focadas no segmento HSH e com estratégias de comunicação mais eficazes, incluindo o desenvolvimento de conhecimento que envolva motivação e habilidade para um comportamento mais seguro.

Palavras-chave: HIV. Síndrome da Imunodeficiência Adquirida. Conhecimento. Teoria da resposta ao item. RDS. HSH. Brasil.

\section{INTRODUCTION}

A reduction trend in the HIV infection incidence has been observed in many countries. However, among men who have sex with men (MSM) the epidemic has increased disproportionately ${ }^{1}$. In low-and middle-income countries, MSM are estimated to be almost 20 times more likely to be infected with HIV compared with the overall population ${ }^{2}$. Even in high-income countries, the HIV epidemic reemerges among MSM as a serious public health problem ${ }^{3}$.

In Brazil, about 883,000 people were estimated to be living with HIV as of June $2017^{4}$, with a high HIV seroprevalence among MSM (17.5\% in 2016) $)^{5}$. In addition, MSM face barriers in the HIV continuum care, from early diagnosis to attaining viral load suppression ${ }^{6,7}$.

Dissemination of information on transmission routes should be widely implemented to promote lower risk behaviors ${ }^{8,9}$. More recently, the use of Pre-exposure (PrEP) and Postexposure (PEP) Prophylaxis, and HIV self-testing were added to the existing strategies to the decision-making process upon potential risk exposures ${ }^{10,11}$. Despite its potentialities, knowledge itself does not necessarily imply changes in unsafe sexual practices ${ }^{12,13}$, which depends both on structural aspects, such as social inequality, stigma, and discrimination ${ }^{14-16}$, and on relational, cultural, and subjective aspects, which are associated with vulnerability to HIV/ AIDS ${ }^{1,17,18}$.

Within this context, HIV/AIDS knowledge can be considered a necessary but not sufficient element for developing an individual's awareness of the risk of infection and a corresponding adoption of preventive strategies. Thus, knowledge consists in a paramount 
element due to its capacity to increase uptake and follow-up in healthcare services of people at higher risk of infection ${ }^{19}$.

Another aspect of knowledge is the attenuation of stigma and discrimination against people living with HIV by disseminating specific information on the forms of prevention and transmission of the virus ${ }^{20-22}$. Thus, monitoring HIV/AIDS knowledge and its associated factors, is important for the formulation, overseeing, and keeping track of public health policies ${ }^{23}$.

There are several ways to obtain and analyze data on HIV / AIDS knowledge. In Brazil, an HIV surveillance study among MSM conducted in 2009 was based on 10 questions recommended by the Joint United Nations Programme on HIV / AIDS (UNAIDS) and the Brazilian Ministry of Health ${ }^{19}$. In this study, recruitment was performed by the Respondent-Driven Sampling (RDS) method, and the data were analyzed by the item response theory (IRT). The ratios of high, medium, and low knowledge were $36.6 \%, 37.4 \%$, and $26 \%$, respectively.

Socioeconomic (e.g., high schooling and monthly income) and behavioral factors (e.g., number of friends or acquaintances who are gay or bisexual, having sex exclusively with men, homosexual sexual orientation, and consistent use of condom) have been associated with high knowledge $\mathrm{e}^{21,24-26}$. Factors related to healthcare services, including HIV testing and the diagnosis of sexually transmitted infections (STI), are also associated with better knowledge about HIV/ AIDS $^{21,25-27}$.

Considering the recent changes in public policies on HIV/AIDS prevention in Brazil, including the introduction of PrEP and the adoption of the combined prevention policy, our study aims to evaluate HIV / AIDS knowledge among MSM from 12 Brazilian cities, in 2016, exploring sociodemographic characteristics, characteristics concerning identity of the participants and, in particular, those related to healthcare services, including potential sources of knowledge acquisition.

\section{METHODOLOGY}

\section{DESIGN AND POPULATION}

This is a cross-sectional study conducted among MSM in 12 Brazilian cities in 2016. Eligibility criteria were: age 18 years old or over; sexual intercourse with another man within 12 months prior to the interview; to live, study, or work in each of the 12 cities. In addition, participants should not have been under the influence of drugs or alcohol at the time of data collection; could not have participated in the study previously; and should have received an invitation from another MSM (valid coupon) to participate in the survey. The research was approved by the Research Ethics Committee of the Federal University of Ceará (CAAE43133915.9.0000.5054 and Opinion no. 1,024,053), and the participants signed an Term of Free and Informed Consent (TFIC).

The sample size in each city was a priori established at 350 participants, and recruitment was conducted using the RDS method. As established in this strategy, the initial 
participants, called "seeds," were chosen in the previous stage of the research through focal groups and in-depth interviews with members of non-governmental organizations (NGOs). Methodological details are available from Kendall et al. ${ }^{28}$

\section{EVENT AND EXPLANATORY VARIABLES}

The event of interest was HIV / AIDS knowledge, measured by 12 questions (items) about transmission/prevention listed in Table 1. For each item, participants were asked whether the statement was "correct," "incorrect," or "did not know." The data were obtained through

Table 1. Assessment of the HIV/AIDS knowledge items among MSM.

\begin{tabular}{|c|c|c|c|c|}
\hline Items & $\begin{array}{c}\text { Correct } \\
\text { answers (\%) }\end{array}$ & Corr. ${ }^{1}$ & Dif. $^{2}$ & Disc. $^{2}$ \\
\hline $\begin{array}{l}\text { 1. There are medicines for HIV-negative } \\
\text { people to take to prevent HIV. }\end{array}$ & 33.5 & 0.268 & $1.21(6.51)$ & $0.36(0.29)$ \\
\hline $\begin{array}{l}\text { 2. An HIV-infected person who is taking AIDS } \\
\text { medication has a lower risk of transmitting } \\
\text { the virus. }\end{array}$ & 51.2 & 0.342 & $-0.07(4.91)$ & $0.41(0.33)$ \\
\hline $\begin{array}{l}\text { 3. An HIV-infected pregnant woman receiving } \\
\text { AIDS medication during prenatal and at } \\
\text { childbirth will have a lower chance of } \\
\text { transmitting the virus to the baby. }\end{array}$ & 74.6 & 0.473 & $-1.25(3.44)$ & $0.61(0.49)$ \\
\hline $\begin{array}{l}\text { 4. There are medicines for HIV/AIDS to be } \\
\text { used after a situation of risk of infection. }\end{array}$ & 71.8 & 0.434 & $-1.16(3.55)$ & $0.56(0.45)$ \\
\hline $\begin{array}{l}\text { 5. People can be infected with HIV if they share } \\
\text { cutlery, cups, or meals. }\end{array}$ & 84.4 & 0.611 & $\begin{array}{l}-1.28 \\
(3.40)\end{array}$ & $1.28(1.02)$ \\
\hline $\begin{array}{l}\text { 6. People can be infected with HIV if they use } \\
\text { public toilets. }\end{array}$ & 79.5 & 0.551 & $-1.09(3.64)$ & $1.14(0.91)$ \\
\hline $\begin{array}{l}\text { 7. People can be infected with HIV if it they are } \\
\text { bitten by mosquitoes. }\end{array}$ & 78.7 & 0.487 & $-1.26(3.43)$ & $0.80(0.64)$ \\
\hline $\begin{array}{l}\text { 8. When having intercourse with only one } \\
\text { faithful partner, not infected with HIV, the } \\
\text { risk of contracting the virus is lower. }\end{array}$ & 74.9 & 0.283 & $-2.10(2.38)$ & $0.33(0.26)$ \\
\hline 9. There is a cure for AIDS. & 82.4 & 0.402 & $-1.86(2.68)$ & $(0,57)(0.46)$ \\
\hline $\begin{array}{l}\text { 10. A healthy-looking person may be infected } \\
\text { with the HIV virus. }\end{array}$ & 96.2 & 0.919 & $-2.32(2.10)$ & $1.30(1.04)$ \\
\hline $\begin{array}{l}\text { 11. People can contract HIV if they share with } \\
\text { other people instruments for the use of } \\
\text { drugs such as syringes, needles etc. }\end{array}$ & 94.8 & 0.684 & $-2.51(1.86)$ & $0.90(0.72)$ \\
\hline $\begin{array}{l}\text { 12. People can contract HIV if they do not use } \\
\text { condoms in sexual intercourse. }\end{array}$ & 96.9 & 0.890 & $-2.55(1.81)$ & $1.19(0.95)$ \\
\hline
\end{tabular}


face-to-face or self-applied interviews with the use of tablets. For this analysis, we selected: sociodemographic indicators (age, schooling, skin color, socioeconomic level, private health insurance); indicators referring to MSM identity and practices (self-reported identity, having sex only with men, communicating their sexual orientation to other people, age of sexual debut, having exchanged sex for money, discrimination due to sexual orientation, chance acquiring HIV infection, and talking to friends about HIV prevention); and those related to healthcare services (knowing where to get HIV test, previous HIV or syphilis testing, history of any STI, to have received condoms, lubricant gel, counseling, or educational material on STI, to have participated in lectures about STI, being a member or participating in NGOs, self-rated overall health, to have sought the same healthcare service whenever necessary, usual source of health care, last medical consultation, and to have participated in the research in order to obtain knowledge about HIV/AIDS).

Regarding "receiving counseling in the last 12 months," the answers were categorized as: "public services," "NGO," "educational institutions," "other," and "did not receive." Since it was possible to separately answer each category, we proceeded with a hierarchization process in which whenever a public service was mentioned, this was prioritized in the classification, followed by the remaining listed options. For the variable "usual source of care," primary healthcare units, emergency healthcare units, specialized services, the family health strategy and general or emergency hospitals were classified as public while medical offices, private clinics, and private general or emergency hospitals were classified as private. In this classification, the remaining answers were classified as not having a usual source of health care.

\section{STATISTICAL ANALYSIS}

HIV / AIDS Knowledge was analyzed by the IRT ${ }^{29,30}$ using the Bilog-MG software ${ }^{31}$. For each item, the answers were verified and coded as correct or incorrect according to a pre-established pattern. The answer "did not know" was categorized as incorrect. Knowledge scores were estimated by the logistic model of 2 parameters (difficulty and discrimination), detailed by Gomes et al. ${ }^{32}$ Initially, the percentage of accuracy of each item was calculated. Then, the parameters of difficulty and discrimination were estimated using the marginal maximum likelihood method ${ }^{33}$. Finally, the estimation of the proficiency of each participant was performed using the Bayesian method. The proficiency scale is an arbitrary scale that assumes a standard normal distribution between $-\infty \mathrm{e}+\infty$, with an average of 0 , and standard deviation of 1 . To better interpret the results, parameters and the estimated scores of knowledge were recalculated, using a scale from 0 to 10 . Finally, the values of the percentiles 75 and 25 were considered cutoff points for grouping the variable in 3 categories of knowledge: high ( $>75)$, medium (75-25), and low $(<25)$. The "high knowledge" category was compared with the "medium" or "low" categories associated.

Initially, for each city the data were weighted by Gile's estimator ${ }^{34}$. The 12 cities were analyzed together, and each one was considered a stratum. Gile's estimator was used to 
calculate the proportions with $95 \%$ confidence interval (95\%CI). | Frequency distribution of categorical variables was presented and the differences between proportions were analyzed by the Chi-square test. Variables with $\mathrm{p}<0.20$ were included in the multivariate logistic regression, starting with sociodemographic variables, followed by those related to MSM practices and identity, and, lastly, those related to healthcare services. Only variables with value of $\mathrm{p}$ $<0.05$ remained in the final model, and odds ratios (OR) with $95 \%$ CI were estimated. Data were analyzed by RDS Analyst and SAS softwares, using complex data analysis procedures.

\section{RESULTS}

We recruited 4,176 MSM in the 12 Brazilian cities. Most participants were 24 years old or less $(58.3 \%)$, had 12 or more years of schooling $(70.4 \%)$, belonged to lower economic classes (C-D-E), and were of nonwhite color/ ethnicity (68.2\%). Only $28.8 \%$ reported having health insurance. There was a predominance of MSM who self-identified as gays/homosexuals $(83.1 \%)$, reported being attracted by men $(88.3 \%)$, and having sex only with men in the last 6 months $(75.5 \%)$. For most of them, sexual debut occurred after 15 years of age (59.5\%), and almost two-thirds (64.5\%) of MSM reported having suffered discrimination due to sexual orientation ever. Exchange of sex for money was reported by $33.3 \%$ of participants, whereas $61.4 \%$ considered having no/ low risk of being infected with HIV, and $59.2 \%$ said they talked about STI with some, a few, or no friends. Most of them reported knowing where to take an HIV test ( $82.3 \%$ ), and $66.2 \%$ were previously tested ever. Regarding syphilis, $41 \%$ had been tested in the last 12 months, and $26.7 \%$ reported having had any diagnosis of STI. Whereas more than three quarters received condoms $(75.4 \%)$ in the last 12 months, many of them did not receive lubricant gel (65.8\%), did not receive any educational material $(63.3 \%)$, did not participate in lectures on STI (77.2\%), and did not receive counseling on STI (61.5\%). Among those who had some counseling on STI, $23.7 \%$, this occurred in healthcare services. Participation in NGOs was low (17.9\%), and more than three quarters $(77.2 \%)$ self-rated their health as very good or good. Finally, $73.5 \%$ sought the same healthcare service whenever they needed, $73.3 \%$ reported that their usual source of care was public, and $80.5 \%$ had medical appointments in the last 12 months.

Regarding the analysis of the items, the proportion of correct answers ranged from $33.5 \%$ to $96.9 \%$ (Table 1). The lowest proportion of correct answers occurred for item $1(33.5 \%)$, followed by item $2(51.2 \%)$. The agreement analysis indicated a very high accuracy index for items 12 (96.9\%), 10 (96.2\%), and 11 (94.8\%). On the other hand, the biserial correlation coefficient ranged from 0.268 to 0.919 , with item 1 obtaining the lowest coefficient (0.268), which indicates a low correlation between correct answers and the total score of the test.

The investigation of the quality of each of the items evaluated in this study showed that the discrimination parameter ranged from 0.33 to 1.30 (Table 1). Items 10, 5, 12, and 6 were considered those with higher discrimination $(1.30 ; 1.28 ; 1.19$; and 1.14 respectively), capable of well differentiating the levels of HIV/AIDS knowledge. Items 1 and 8 presented with 
low discrimination, and items 2, 3, 4, 7, and 9 presented with moderate discrimination ${ }^{29,30}$. Difficulty parameters indicated that items 12,11 , and 10 were considered extremely easy; item 2 , difficult; and item 1 , very difficult. The others were considered easy.

The knowledge score generated by the IRT in the scale from 0 to 10 ranged from 0.2918 to 6.7547 , and was classified as low (0.2918 to 4.2861), medium (4.2664 to 5.8873), or high (5.9367 to 6.7547). The overall proportion of high level of knowledge (percentile $>75 \%$ ) accounted only for $23.7 \%(95 \% \mathrm{CI}=20.8-26.6)$, ranging from $5.2 \%$ in Fortaleza to $34.2 \%$ in São Paulo. Regarding sociodemographic variables, those with 25 years old or more, with better schooling, of white skin color, and who had a health insurance had statistically higher proportions of high knowledge $(\mathrm{p}<0.05)$ (Table 2$)$. Those within the economic class A-B also presented higher proportion of high knowledge, but without statistical significance $(\mathrm{p}=$ $0.100)$. Regarding the variables related to MSM practices/identity, there were higher proportions of high knowledge among those who identified themselves as gays/homosexuals (27.7\%), who had communicated their sexual orientation to someone $(27.9 \%)$, and who had sex only with men in the last 6 months $(30.7 \%)(\mathrm{p}<0.05)$. Those whose sexual debut occurred after the age of 15 years old also had a higher proportion of high knowledge $(28.5 \%)$, but only statistically borderline $(\mathrm{p}=0.082)$. Those who reported never having exchanged sex for money, and who had moderate to high risk perception of being infected with HIV, had higher proportions of high level of knowledge $(\mathrm{p}<0.01)$. Finally, although not statistically significant, sharing STI prevention information with all or most of their friends indicated a higher proportion of high knowledge.

Table 2. Factors associated with high level of HIV/AIDS knowledge.

\begin{tabular}{|c|c|c|c|}
\hline Characteristics & Total & $\begin{array}{l}\text { Knowledge } \\
\text { high }^{1} \text { n }(\%)^{2}\end{array}$ & p-value \\
\hline \multicolumn{4}{|l|}{ Sociodemographic } \\
\hline \multicolumn{3}{|l|}{ Age (years old) } & \multirow{3}{*}{0.003} \\
\hline $25+$ & 1,626 & $489(29.4)$ & \\
\hline$<25$ & 2,503 & $558(20.2)$ & \\
\hline \multicolumn{4}{|l|}{ Schooling (years) } \\
\hline $12+$ & 3,115 & $910(28.6)$ & \multirow{2}{*}{$<0.001$} \\
\hline$<12$ & 1.017 & $136(13)$ & \\
\hline \multicolumn{4}{|l|}{ Skin color } \\
\hline White & 1,285 & $427(39.5)$ & \multirow{2}{*}{$<0.001$} \\
\hline Nonwhite & 2,821 & $629(20.1)$ & \\
\hline \multicolumn{4}{|l|}{ Brazilian criterion of economic class } \\
\hline$A-B$ & 1,889 & $574(29.1)$ & \multirow{2}{*}{0.100} \\
\hline C-D-E & 2,238 & 483 (23.9) & \\
\hline
\end{tabular}


Table 2. Continuation.

\begin{tabular}{|c|c|c|c|}
\hline Characteristics & Total & 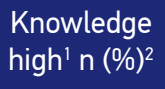 & p-value \\
\hline \multicolumn{4}{|l|}{ Have private health insurance: } \\
\hline Yes & 1,251 & $397(34.5)$ & \multirow{2}{*}{0.001} \\
\hline No & 2,830 & $658(22.9)$ & \\
\hline
\end{tabular}

Self-reported sexual identity

\begin{tabular}{|l|c|c|c|}
\hline Heterosexual/bisexual/other & 586 & $86(17.8)$ & \multirow{2}{*}{0.017} \\
\cline { 1 - 3 } Gay/homosexual & 3,539 & $971(27.7)$ & \\
\hline
\end{tabular}

Have communicated to someone their sexual y attraction to men

\begin{tabular}{|c|c|c|c|}
\hline No & 272 & $31(12.3)$ & \multirow{2}{*}{0.002} \\
\hline Yes & 3,826 & $1,024(27.9)$ & \\
\hline \multicolumn{4}{|c|}{ Sex only with men in the last 6 months } \\
\hline No & 707 & $116(16)$ & \multirow{2}{*}{0.002} \\
\hline Yes & 3,124 & $913(30.7)$ & \\
\hline \multicolumn{4}{|c|}{ Age of sexual debut (years old) } \\
\hline $15+$ & 2,319 & $637(28.5)$ & \multirow{2}{*}{0.082} \\
\hline$<15$ & 1,752 & $413(22.8)$ & \\
\hline
\end{tabular}

Felt discriminated due to sexual orientation

\begin{tabular}{|l|c|c|c|}
\hline No & 1,234 & $229(18)$ & 0 \\
\hline Yes & 2,863 & $827(30.7)$ & 0.003 \\
\hline
\end{tabular}

Received money in exchange for sex at ever

\begin{tabular}{|c|c|c|c|}
\hline No & 2,729 & $781(30,6)$ & \multirow{2}{*}{$<0.001$} \\
\hline Yes & 1,283 & $259(17.4)$ & \\
\hline \multicolumn{4}{|c|}{ Current chance of acquiring HIV } \\
\hline Moderate/high & 988 & $268(26.4)$ & \multirow{3}{*}{0.012} \\
\hline None/low & 2,628 & $618(23.3)$ & \\
\hline Do not know & 138 & $10(6)$ & \\
\hline
\end{tabular}

Share with friends STI prevention information

\begin{tabular}{l|c|c|c} 
All/most & 1,903 & $531(29.5)$ & 0.084 \\
Some/a few/none & 2,166 & $520(24)$ & \\
& & & Continue...
\end{tabular}


Table 2. Continuation.

\begin{tabular}{|c|c|c|c|}
\hline Characteristics & Total & $\begin{array}{l}\text { Knowledge } \\
\text { high }^{1} \text { n }(\%)^{2}\end{array}$ & p-value \\
\hline \multicolumn{4}{|l|}{ Related to healthcare services } \\
\hline \multicolumn{4}{|l|}{ Know where to take an HIV test } \\
\hline Yes & 3,445 & $967(29)$ & \multirow{2}{*}{$<0.001$} \\
\hline No & 681 & $90(12.2)$ & \\
\hline \multicolumn{4}{|l|}{ Previous HIV testing ever } \\
\hline Yes & 2,896 & $887(31.5)$ & \multirow{2}{*}{$<0.001$} \\
\hline No & 1,226 & $170(15.4)$ & \\
\hline \multicolumn{4}{|c|}{ Previous syphilis testing in the last 12 months } \\
\hline Yes & 1,643 & $569(35.2)$ & \multirow{2}{*}{$<0.001$} \\
\hline No & 2,456 & $484(19.6)$ & \\
\hline \multicolumn{4}{|l|}{ History of any STI diagnosis ${ }^{3}$} \\
\hline Yes & 1,055 & $361(38.1)$ & \multirow{2}{*}{$<0.001$} \\
\hline No & 3,023 & $690(21.3)$ & \\
\hline \multicolumn{4}{|c|}{ Received free condoms in the last 12 months } \\
\hline Yes & 3,001 & $788(27)$ & \multirow{2}{*}{0.299} \\
\hline No & 1,112 & $268(23.4)$ & \\
\hline \multicolumn{4}{|c|}{ Received educational material on STI in the last 12 months } \\
\hline Yes & 1,626 & $486(35.5)$ & \multirow{2}{*}{$<0.001$} \\
\hline No & 2,256 & $515(20.8)$ & \\
\hline \multicolumn{4}{|c|}{ Participated in lectures on STI in the last 12 months } \\
\hline Yes & 882 & $276(34.9)$ & 0.006 \\
\hline No & 3,002 & $726(23.6)$ & \\
\hline \multicolumn{4}{|c|}{ Received counseling on STI in the last 12 months } \\
\hline In healthcare services & 936 & $311(31.4)$ & \multirow{5}{*}{0.086} \\
\hline In NGOs & 150 & $45(30.3)$ & \\
\hline In educational institutions & 191 & $38(15.9)$ & \\
\hline In other locations & 168 & $50(16.4)$ & \\
\hline Did not receive & 2,256 & $539(25.7)$ & \\
\hline \multicolumn{4}{|l|}{ Participates or is a member of $\mathrm{NGOs}$} \\
\hline Yes & 741 & $249(33.5)$ & \multirow{2}{*}{0.026} \\
\hline No & 3,335 & $803(24.5)$ & \\
\hline
\end{tabular}


Table 2. Continuation.

\begin{tabular}{|c|c|c|c|}
\hline Characteristics & Total & 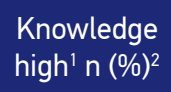 & p-value \\
\hline \multicolumn{4}{|l|}{ Self-rated health } \\
\hline Very good/good & 3,201 & $869(27.7)$ & \multirow{2}{*}{0.099} \\
\hline Regular/bad/very bad & 884 & $186(21.4)$ & \\
\hline \multicolumn{4}{|l|}{ Usual source of care } \\
\hline Public & 2,836 & $677(24.1)$ & \multirow{3}{*}{$<0.001$} \\
\hline Private & 989 & $334(36.4)$ & \\
\hline None/do not know/other & 280 & $45(12.5)$ & \\
\hline \multicolumn{4}{|l|}{ Last medical appointment } \\
\hline$<12$ months & 3,297 & $908(27.6)$ & \multirow{2}{*}{0.026} \\
\hline $12+$ months & 829 & $149(19.5)$ & \\
\hline
\end{tabular}

Regarding the variables related to healthcare services, there were higher proportions of high level of knowledge among those who knew where to take an HIV test, who had previously been tested for HIV ever, who had takena syphilis test in the last 12 months, and who had had any STI diagnosis ever $(\mathrm{p}<0.001)$. It is noteworthy that receiving condoms or counseling on STI were not statistically associated with high knowledge. Nevertheless, receiving counseling in healthcare services $(31.4 \%)$ or in NGOs $(30.3 \%)$ were factors that presented higher proportions of high knowledge, while receiving counseling in educational institutions had the lowest proportion (15.9\%). Participating in lectures or having access to educational material on STI had statistically significant higher proportions of high knowledge $(\mathrm{p}<0.001)$. Moreover, there were higher proportions of high knowledge between those who reported participating in NGOs and whose self-rated overall health was very good/good, although this was not statistically significant. Finally, having had the last medical appointment in the last 12 months indicated higher knowledge $(27.6 \%)(p=0.026)$. It is also noteworthy that the highest proportion of high knowledge occurred among those whose usual source of care was private $(36.4 \%)$, compared to public $(24.1 \%)$ or none/ did not know/other $(12.5 \%)(\mathrm{p}<0.001)$.

The multivariate analysis (Table 3 ) indicated that the following variables were positively associated with a high HIV / AIDS knowledge level: age 25+ years old, $12+$ years of schooling, white skin color, having private health insurance, having suffered discrimination due to sexual orientation, previous syphilis testing in the last 12 months, and having received educational material in the last 12 months. Having received money for sex was negatively associated with high level of knowledge. 
Table 3. Multivariate analysis ${ }^{1}$ of high level of HIV/AIDS knowledge.

\begin{tabular}{l|c|c}
\hline \multicolumn{1}{|c|}{ Characteristics } & OR $(95 \% \mathrm{Cl})^{2}$ & $p$-value \\
\hline Age (25+ years old) & $1.99(1.42-2.80)$ & $<0.001$ \\
\hline Schooling (12+ years) & $1.92(1.18-3.13)$ & 0.009 \\
\hline White skin color & $2.35(1.64-3.77)$ & $<0.001$ \\
\hline Having private health insurance & $1.45(0.99-2.11)$ & 0.054 \\
\hline Suffered discrimination due to sexual orientation & $1.57(1.04-2.36)$ & 0.031 \\
\hline Exchanged sex for money in the last 6 months & $0.61(0.40-0.93)$ & 0.020 \\
\hline Previous syphilis testing in the last 12 months & $1.78(1.24-2.55)$ & 0.002 \\
\hline Received educational material on STI in the last 12 months: & $1.76(1.21-2.56)$ & 0.003 \\
\hline $\begin{array}{l}\text { ' Logistic regression; }{ }^{2} \text { Weighted odds ratio (95\% confidence interval) comparing high level of knowledge to medium/ } \\
\text { low; STI: Sexually transmitted infection. }\end{array}$ & &
\end{tabular}

\section{DISCUSSION}

Although we are currently facing the third decade of the HIV / AIDS epidemic, the proportion of respondents who presented a high level of knowledge was low (23.7\%) and lower than that observed in a previous study $(36.6 \%)$ performed in 10 Brazilian cities $^{19}$. The heterogeneity among the cities is highlighted. Although different instruments and analyses are used, our results corroborate other studies conducted in different countries, whose authors have also demonstrated a low percentage of MSM with a high level of knowledge. In Argentina, Pando et al. ${ }^{26}$ identified a median of 11 correct answers on 18 questions, and only $2.6 \%$ of the participants responded to all items correctly. Another study conducted in Finland demonstrates that the proportion of participants with a high level of knowledge accounted for $18.3 \%{ }^{27}$.

In our study, those with better schooling presented greater HIV/AIDS knowledge, in agreement with studies conducted in Brazil and in other countries ${ }^{19,21,25-27,35}$. It is also noteworthy the association between high level of knowledge, being white, and having private health insurance - important proxy variables that indicate belonging to higher social strata. On the other hand, several studies also indicate that nonwhite MSM have less knowledge when compared to white people $e^{25,36}$. The association of age with a better level of knowledge is controversial in the literature. In some studies, younger populations have higher knowledge ${ }^{24,36}$, whereas in others age did not show any differences or there were lower levels of knowledge at the extremes of the sample $e^{25,37}$.

The difficulty encountered by the participants in answering questions regarding more current topics, such as PrEP, demonstrates that HIV / AIDS knowledge remains restricted to more traditional aspects such as the appearance of people with AIDS and forms of contamination and prevention. Therefore, overall, knowledge about combined prevention is still incipient. The novelty represented by PrEP, incorporated by the Brazilian Unified Health System only after the end of this research, may explain the lack of knowledge of this strategy on 
the part of MSM. It should be noted the negative association with high knowledge of MSM who reported exchanging sex for money, a group that would certainly benefit from PrEP.

Few variables related to health services remained associated with high level of knowledge in the multivariate analysis: previous syphilis testing and having received educational material on STI. In the literature, both, previous HIV testing and having had an STI diagnosis, have been associated with a higher level of knowledge $e^{21,25-27}$. STI/HIV testing seems to be an opportunity to disseminate information. These results indicate scarce investment in public policies, both in the area of health and education, and in activities related to prevention, information, and counseling. Information seems to be restricted to the distribution of educational materials, evidencing lost opportunities. The availability of preventive measures seems to be unrelated to information and campaigns aimed at the general population, which still focus their message on the use of condom. Calazans et al. ${ }^{38}$ indicate a setback in the scope of responses and governmental actions in documents that support AIDS policies in Brazil, especially by neglecting gays and other MSM. The authors emphasize that the governmental documents identified and analyzed are administrative provisions that can be revoked or modified as managers alternate within the system.

The association between having suffered discrimination due to sexual orientation and the highest level of HIV / AIDS knowledge suggests that recognizing one's discrimination is indicative of a broader recognition of their sexual orientation and rights. In this sense, the literature highlights the association between self-reported sexual identity as gay/homosexual and better knowledge, a result also found in this study ${ }^{21,25,26,36}$.

HIV/AIDS Knowledge was measured through 12 questions and analyzed considering the IRT. This methodology enabled us to identify, among the questions, which ones had the greatest power of discrimination. According to our analysis, 4 items were capable to well differentiate the levels of HIV/ AIDS knowledge among MSM. Therefore, knowledge among this population can potentially be assessed through a shorter instrument, as a means of optimizing resources. On the other hand, as suggested by other authors ${ }^{26}$, it is worth including issues related to the course of the disease, treatment, and new preventive strategies that have been disseminated in different countries. In addition, it is necessary to investigate the response to campaigns aimed at disseminating information on STI and HIV / AIDS, including those run in the media by governmental programs and NGOs.

\section{CONCLUSIONS}

This study indicates the need for prevention policies focused on MSM and with more effective communication strategies. Although information is necessary, knowledge must be provided by developing motivation and ability towards a safer behavior ${ }^{36}$. These results should be interpreted with caution. Since this is a cross-sectional RDS study, we cannot generalize the results to the entire MSM population of the studied capitals, nor interpret them as causal relationships. Moreover, heterogeneity among the cities indicates the need to evaluate specific local MSM contexts. 


\section{REFERENCES}

1. Beyrer C, Baral SD, Van Griensven F, Goodreau SM, Chariyalertsak S, Wirtz AL, et al. Global epidemiology of HIV infection in men who have sex with men. Lancet. 2012;380(9839):367-77. https: / / doi.org/10.1016/S0140-6736(12)60821-6

2. Baral S, Sifakis F, Cleghorn F, Beyrer C. Elevated risk for HIV infection among men who have sex with men in low- and middle-income countries 2000-2006: a systematic review. PLoS Med. 2007;4(12):1901-11. https: / / doi.org/10.1371/journal.pmed.0040339

3. Sullivan PS, Hamouda O, Delpech V, Geduld JE, Prejean J, Semaille C, et al. Reemergence of the HIV epidemic among men who have sex with men in North America, Western Europe, and Australia, 1996-2005. Ann Epidemiol. 2009;19(6):423-31. https: / / doi.org/10.1016/j.annepidem.2009.03.004

4. Brasil. Ministério da Saúde. Secretaria de Vigilância em Saúde. Departamento de DST, Aids e Hepatites Virais. Boletim Epidemiológico: aids e DST. Brasília, DF; 2017

5. Kerr L, Kendall C, Guimarães MDC, Salani Mota R, Veras MA, Dourado I, et al. HIV prevalence among men who have sex with men in Brazil. Medicine. 2018;97(1S Suppl 1):S9-S15. https: / / doi.org/10.1097/ MD.0000000000010573

6. Hoffmann M, MacCarthy S, Batson A, CrawfordRoberts A, Rasanathan J, Nunn A, et al. Barriers along the care cascade of HIV-infected men in a large urban center of Brazil. Aids Care. 2016;28(1):57-62. https: / / doi.org/10.1080/09540121.2015.1062462

7. Millett GA, Peterson JL, Flores SA, Hart TA, Jeffries WL 4th, Wilson PA, et al. Comparisons of disparities and risks of HIV infection in black and other men who have sex with men in Canada, UK, and USA: a metaanalysis. Lancet. 2012;380(9839):341-8. https: / doi. org/10.1016/S0140-6736(12)60899-X

8. Vian T, Semrau K, Hamer DH, Loan Le TT, Sabin LL. HIV/Aids-Related knowledge and behaviors among most-at-risk populations in Vietnam. Open Aids J. 2012;6(1):259-65. https: / / doi.org/ 10.2174/1874613601206010259

9. Sohn A, Cho B. Knowledge, attitudes, and sexual behaviors in HIV/Aids and predictors affecting condom use among men who have sex with men in South Korea. Osong Public Health Res Perspect. 2012;3(3):156-64. https:// doi.org/10.1016/j. phrp.2012.07.001

10. Terto Jr V. Different prevention methods lead to different choices? Questions on HIV/Aids prevention for men who have sex with men and other vulnerable populations. Rev Bras Epidemiol. 2015;18(Suppl 1):156-68. https:/ / dx.doi. org/10.1590/1809-4503201500050012

11. Grangeiro A, Ferraz D, Calazans G, Zucchi EM, Díaz-Bermúdez XP. O efeito dos métodos preventivos na redução do risco de infecção pelo HIV nas relações sexuais e seu potencial impacto em âmbito populacional: uma revisão da literatura. Rev Bras Epidemiol. 2015;18(Suppl 1):43-62. https: / dx.doi. org/10.1590/1809-4503201500050005

12. Oliveira DC, Pontes APM, Gomes AMT, Ribeiro MCM. Conhecimentos e práticas de adolescentes acerca das DST/HIV/aids em duas escolas públicas municipais do Rio de Janeiro. Esc Anna Nery Rev Enferm. 2009;13(4):833-41. http:/ / dx.doi. org/10.1590/S1414-81452009000400020

13. Nelson LRE, Wilton L, Agyarko-Poku T, Zhang N, Aluoch M, Thach CT, et al. The association of HIV stigma and HIV/STD knowledge with sexual risk behaviors among adolescent and adult men who have sex with men in Ghana, West Africa. Res Nurs Health. 2015;38(3):194-206. http:/ / doi.org/10.1002/ nur. 21650

14. Frye V, Nandi V, Egan J, Cerda M, Greene E, Tieu HV, et al. Sexual orientation- and race-based discrimination and sexual HIV risk behavior among urban MSM. Aids Behav. 2015;19(2):257-69. http:// doi.org/10.1007/ s10461-014-0937-2

15. Mizuno Y, Borkowf C, Millett G, Bingham T, Ayala G, Stueve A. Homophobia and racism experienced by Latino men who have sex with men in the United States: correlates of exposure and associations with HIV risk behaviors. Aids Behav. 2012;16(3):724-35. http: / / doi.org/10.1007/s10461-011-9967-1

16. Magno L, Dourado I, Silva LAVD, Brignol S, Amorim L, MacCarthy S. Gender-based discrimination and unprotected receptive anal intercourse among transgender women in Brazil: a mixed methods study. PLoS One. 2018;13(4):e0194306. http: / / doi. org/10.1371/journal.pone.0194306

17. Altman D, Aggleton P, Williams M, Kong T, Reddy V, Harrad D, et al. Men who have sex with men: stigma and discrimination. Lancet. 2012;380(9839):439-45. http:/ / doi.org/10.1016/S0140-6736(12)60920-9

18. Silva LAD. Pleasure without condom: new positionings on online interaction networks. Cad Pagu. 2010;(35):241-77. http:/ / dx.doi.org/10.1590/ S0104-83332010000200009 
19. Gomes RRFM, Ceccato MGB, Kerr LRFS, Guimarães MDC. Fatores associados ao baixo conhecimento sobre $\mathrm{HIV}$ / aids entre homens que fazem sexo com homens no Brasil. Cad Saúde Pública. 2017;33(10):e00125515. http: / / dx.doi.org/10.1590/0102-311x00125515

20. Santos VP, Coelho MTÁD, Macário EL, Oliveira TCS. Existe relação entre o conhecimento de estudantes a respeito das formas de contágio do HIV/aids e suas respostas sobre a proximidade com soropositivos? Ciênc Saúde Coletiva. 2017;22(8):2745-52. http://dx.doi. org/10.1590/1413-81232017228.25892015

21. Liao M, Wang M, Shen X, Huang P, Yang X, Hao L, et al. Bisexual behaviors, HIV knowledge, and stigmatizing/ discriminatory attitudes among men who have sex with men. PLoS One. 2015;10(6):e0130866. http://doi. org/10.1371/journal.pone.0130866

22. Tavoosi A, Zaferani A, Enzevaei A, Tajik P, Ahmadinezhad Z. Knowledge and attitude towards HIV/Aids among Iranian students. BMC Public Health. 2004;17(4):1-16. http:/ / doi.org/ 10.1186/1471-2458-4-17

23. Holtzman D, Lowry R, Kann L, Collins JL, Kolbe LJ. Changes in HIV-related information sources, instruction, knowledge, and behaviors among US high school students, 1989 and 1990. Am J Public Health. 1994;84(3):388-93.

24. Ma W, Wu G, Zheng H, Zhang W, Peng Z, Yu R. Prevalence and risk factors of HIV and syphilis, and knowledge and risk behaviors related to HIV/Aids among men who have sex with men in Chongqing, China.JBiomed Res. 2016;30(2):101-11. http:// doi.org/ 10.7555/JBR.30.20150057

25. Wagenaar BH, Sullivan PS, Stephenson R. HIV knowledge and associated factors among internetusing men who have sex with men (MSM) in South Africa and the United States. PLoS One. 2012;7(3):e32915. http:// doi.org/10.1371/journal. pone. 0032915

26. Pando MA, Balan I, Marone R, Dolezal C, Barreda V, Carballo Dieguez A, et al. HIV knowledge and beliefs among men who have sex with men (MSM) in Buenos Aires, Argentina. Aids Behav. 2013;17(4):1305-12. http://doi.org/10.1007/s10461-012-0404-x

27. Suominen T, Heikkinen T, Pakarinen M, Sepponen AM, Kylmä J. Knowledge of HIV infection and other sexually transmitted diseases among men who have sex with men in Finland. BMC Infect Dis. 2017;17(1):121. http:/ / doi.org/10.1186/s12879-0172203-5

28. Kendall C, Kerr L, Mota RS, Guimarães MDC, Leal AF, Merchan-Hamann E, et al. The 12 city HIV surveillance survey among MSM in Brazil 2016 using respondent-driven sampling: a description of methods and RDS diagnostics. Rev Bras Epidemiol. 2019;14(22):e190004. http:// doi.org/ 10.1590/1980-549720190004

29. Vendramini CMM, Silva MC, Canale M. Análise de itens de uma prova de raciocínio estatístico. Psicol Estud. 2004;9(3):487-98. http:/ / dx.doi.org/10.1590/ S1413-73722004000300017

30. Baker FB. The basics of item response theory. Boston: Lawrence Rudner; 2001.

31. Toit, M. IRT from SSI: Bilog-MG, Multilog, Parscale, Testfact. Lincolnwood: Scientific Software International; 2003.

32. Gomes RRFM, Batista JR, Ceccato MGB, Kerr LRFS, Guimarães MDC. HIV/Aids knowledge among men who have sex with men: applying the item response theory. Rev Saúde Pública. 2014;48(2):206-15. http:/ / doi.org/10.1590/S0034-8910.2014048004911

33. Bock RD, Aitkin M. Marginal maximum likelihood estimation of item parameters: application of an EM algorithm. Psychometrika. 1981;46(4):443-59. https:/ / doi.org/10.1007/BF02293801

34. Gile KJ, Handcock MS. Respondent-driven sampling: an assessment of current methodology. Sociol Methodol. 2010;40(1):285-327. https:// doi.org/ 10.1111/j.1467-9531.2010.01223.x

35. Garofalo R, Gayles T, Bottone PD, Ryan D, Kuhns LM, Mustanski B. Racial/ethnic differences in HIVrelated knowledge among young men who have sex with men and their association with condom errors. Health Educ J. 2015;74(5):518-30. https: / / doi.org/ $10.1177 / 0017896914549485$

36. Sharma A, Kahle EM, Sullivan SP, Stephenson R. Birth cohort variations across functional knowledge of HIV prevention strategies, perceived risk, and HIVassociated behaviors among gay, bisexual, and other men who have sex with men in the United States. Am J Mens Health. 2018;12(6):1824-34. https:/ / doi. org/10.1177/1557988318790875

37. Jaspal R, Lopes B, Jamal Z, Yap C, Paccoud I, Sekhon P. HIV knowledge, sexual health and sexual behaviour among black and minority ethnic men who have sex with men in the UK: a cross-sectional study. Sex Health. 2018;16(1)25-31. https:// doi.org/10.1071/ $\mathrm{SH} 18032$

38. Calazans GJ, Pinheiro TF, Ayres JRCM. Vulnerabilidade programática e cuidado público: panorama das políticas de prevenção do HIV e da aids voltadas para gays e outros HSH no Brasil. Sex Salud Soc. 2018;(29):26393. http:/ / dx.doi.org/10.1590/1984-6487 
Acknowledgements: the authors would like to thank the funding on the part of the Brazilian Ministry of Health, through the Department of Health Surveillance and the Department of Surveillance, Prevention and Control of STD, HIV/Aids and Viral Hepatitis. The authors also thank all interviewees, without whom this study would not be possible.
Authors' contribution: Guimarães MDC conceived the study, analyzed the data, wrote and revised the manuscript. Ceccato MGB and Gomes RRFM contributed to the analysis of the data, as well as the writing and editing of the manuscript. Magno L, Leal AF and Knauth DR revised and edited the article. All authors revised and approved the final version of the text. 